Pacific Journal of Mathematics

POLYNOMIALS AND HAUSDORFF MATRICES 


\section{POLYNOMIALS AND HAUSDORFF MATRICES}

\section{Philip C. TONNe}

If $f$ is a function from the rational numbers in $[0,1]$ to the complex plane and $c$ is a complex sequence, then the Hausdorff matrix $H(c)$ for $c$ and a sequence $L(f, c)$ are defined:

$$
\begin{gathered}
H(c)_{n p}=\left(\begin{array}{l}
n \\
p
\end{array}\right) \sum_{q=0}^{n-p}(-1)^{q}\left(\begin{array}{c}
n-p \\
q
\end{array}\right) c_{p+q}=\left(\begin{array}{l}
n \\
p
\end{array}\right) \Delta^{n-p} c_{p} \\
L(f, c)_{n}=\sum_{p=0}^{n} H(c)_{n p} f(p / n) .
\end{gathered}
$$

THEOREM. If $f$ is a function from the rationals in $[0,1]$ to the plane and $L(f, c)$ converges for each complex sequence $c$, then $f$ is a subset (contraction) of a polynomial.

J. S. MacNerney [2, p. 56] and A. Jakimovski [1] have shown:

THEOREM A. If $f$ is a polynomial and $c$ is a complex sequence then $L(f, c)$ converges.

Our theorem is a converse to Theorem A and an improvement of Theorem 7 of [3] where we proved that if $f$ is a continuous function from $[0,1]$ to the complex plane and $L(f, c)$ converges for each complex sequence $c$, then $f$ is a subset of a polynomial.

Lemma 1. Suppose that $M$ is an infinite complex matrix and $M$ transforms each sequence to a bounded sequence. Then there is a positive integer $P$ such that if $p$ is an integer exceeding $P$ then $M_{n p}=0, n=0,1, \cdots$.

Lemma 2, which follows, is not necessary for our result. It is included because it gives an interesting way of proving Lemma 3. The proof for Lemma 3 given here is due to the referee. It is simpler and more direct than the author's argument which uses Lemma 2. The author is grateful to the referee for the pretty proof of Lemma 3 which appears in this paper.

Lemma 2. Suppose that $n$ is a positive integer, each of $\left\{a_{p}\right\}_{1}^{n}$ and $\left\{b_{p}\right\}_{1}^{n}$ is an increasing sequence of nonnegative integers, $M$ is an $n \times$ $n$ matrix such that

$$
M_{m p}=\left(\begin{array}{c}
a_{m} \\
b_{p}
\end{array}\right) \quad(m, p=1,2, \cdots, n)
$$


and $a_{k} \geqq b_{k}, k=1,2, \cdots, n$. Then the determinant of $M$ is positive.

LEMMA 3. Suppose that $f$ is a function from the rationals in $[0,1]$ to the complex plane, $P$ is a nonnegative integer, and

$$
\sum_{q=0}^{p}(-1)^{q}\left(\begin{array}{l}
p \\
q
\end{array}\right) f(q / n)=0
$$

for each integer-pair $\{n, p\}$ satisfying $P<p \leqq n$. Then $f$ is a subset of a polynomial.

Lemma 1 is known. Also, its proof is not difficult.

Lemma 2 is Theorem 2 of [4]. (This present paper was the motivation for [4].)

Proof of Lemma 3. Suppose that each of $p$ and $n$ is an integer and $P<p \leqq n$. For each number $x$ let $Q(x)$ be

$$
\sum_{k=0}^{P}\left(\begin{array}{l}
x \\
k
\end{array}\right) \sum_{q=0}^{k}(-1)^{k+q}\left(\begin{array}{l}
k \\
q
\end{array}\right) f(q / n)
$$

(here $\left(\begin{array}{l}x \\ 0\end{array}\right)=1$ and $\left.\left(\begin{array}{c}x \\ k+1\end{array}\right)=(x-k) /(k+1)\left(\begin{array}{l}x \\ k\end{array}\right), k=0,1,2, \cdots\right)$, and let $H_{n}(x)$ be $Q(n x) . \quad H_{n}$ is a polynomial of degree $P$, at most, and

$$
H_{n}(j / n)=f(j / n) \quad(j=0,1, \cdots, n) .
$$

Now, if $m$ is a multiple of $n, H_{m}=H_{n}$, since each of $H_{m}$ and $H_{n}$ is a polynomial of degree $P$, at most, $P<n$, and $H_{m}$ and $H_{n}$ agree at $0,1 / n, 2 / n, \cdots, n / n$.

Consequently, if $n$ and $m$ are integers exceeding $P, H_{n}=H_{m \cdot n}=$ $H_{m}$. Now, let $n$ be $P+1$ and let $s$ be a positive integer and let $r$ be an integer in $[0, s]$. Then

$$
H_{n}\left(\frac{r}{s}\right)=H_{n}\left(\frac{r n}{s n}\right)=H_{s n}\left(\frac{r n}{s n}\right)=f\left(\frac{r n}{s n}\right)=f\left(\frac{r}{s}\right),
$$

and $f$ is a subset of the polynomial $H_{n}$.

Proof of Theorem. Let $c$ be a complex sequence. For each positive integer $n$,

$$
L(f, c)_{n}=\sum_{p=0}^{n} c_{p}\left(\begin{array}{l}
n \\
p
\end{array}\right) \sum_{q=0}^{p}(-1)^{p+q}\left(\begin{array}{l}
p \\
q
\end{array}\right) f(q / n) .
$$

Define

$$
M_{n p}=\left(\begin{array}{c}
n \\
p
\end{array}\right) \sum_{q=0}^{p}(-1)^{p+q}\left(\begin{array}{c}
p \\
q
\end{array}\right) f(q / n) \quad(n=1,2, \cdots ; p=0,1, \cdots, n)
$$


and $M_{n p}=0$ if $n=0$ or $p>n$. By hypothesis $M$ transforms each sequence to a convergent sequence, so, by Lemma 1 , there is a positive integer $P$ such that if $p$ is an integer exceeding $P$ then $M_{n p}=$ $0, n=0,1, \cdots$.

Thus, by Lemma $3, f$ is a subset of a polynomial.

\section{REFERENCES}

1. A. Jakimovski, Some remarks on the moment problem of Hausdorff, J. London Math. Soc., 33 (1958), 1-13.

2. J. S. Mac Nerney, Hermitian moment sequences, Trans. Amer. Soc., 103 (1962), 45-81.

3. Philip C. Tonne, Power-series and Hausdorff matrices, Pacific J. Math., 21 (1967), 189-198.

4. - A regular determinant of binomial coefficients, Proc. Amer. Math. Soc., 41 (1973), 17-23.

Received October 12, 1972 and in revised form February 26, 1973.

EMORY UNIVERSITY 



\section{PACIFIC JOURNAL OF MATHEMATICS}

\section{EDITORS}

RICHARD ARENS (Managing Editor)

University of California

Los Angeles, California 90024

\section{R. A. Beaumont \\ University of Washington \\ Seattle, Washington 98105}

\section{J. DugundjI*}

Department of Mathematics University of Southern California Los Angeles, California 90007

D. Gilbarg and J. Milgram

Stanford University

Stanford, California 94305

\section{ASSOCIATE EDITORS}
E. F. BeCKenBaCH
B. H. NeumanN
F. WOLF
K. YoSHIDA

\section{SUPPORTING INSTITUTIONS}

\author{
UNIVERSITY OF BRITISH COLUMBIA \\ CALIFORNIA INSTITUTE OF TECHNOLOGY \\ UNIVERSITY OF CALIFORNIA \\ MONTANA STATE UNIVERSITY \\ UNIVERSITY OF NEVADA \\ NEW MEXICO STATE UNIVERSITY \\ OREGON STATE UNIVERSITY \\ UNIVERSITY OF OREGON \\ OSAKA UNIVERSITY
}

\author{
UNIVERSITY OF SOUTHERN CALIFORNIA \\ STANFORD UNIVERSITY \\ UNIVERSITY OF TOKYO \\ UNIVERSITY OF UTAH \\ WASHINGTON STATE UNIVERSITY \\ UNIVERSITY OF WASHINGTON

$* * *$
$*$
AMERICAN MATHEMATICAL SOCIETY
NAVAL WEAPONS CENTER

The Supporting Institutions listed above contribute to the cost of publication of this Journal, but they are not owners or publishers and have no responsibility for its content or policies.

Mathematical papers intended for publication in the Pacific Journal of Mathematics should be in typed form or offset-reproduced, (not dittoed), double spaced with large margins. Underline Greek letters in red, German in green, and script in blue. The first paragraph or two must be capable of being used separately as a synopsis of the entire paper. Items of the bibliography should not be cited there unless absolutely necessary, in which case they must be identified by author and Journal, rather than by item number. Manuscripts, in duplicate if possible, may be sent to any one of the four editors. Please classify according to the scheme of Math. Rev. Index to Vol. 39. All other communications to the editors should be addressed to the managing editor, or Elaine Barth, University of California, Los Angeles, California, 90024.

100 reprints are provided free for each article, only if page charges have been substantially paid. Additional copies may be obtained at cost in multiples of 50 .

The Pacific Journal of Mathematics is issued monthly as of January 1966. Regular subscription rate: $\$ 60.00$ a year (6 Vols., 12 issues). Special rate: $\$ 30.00$ a year to individual members of supporting institutions.

Subscriptions, orders for back numbers, and changes of address should be sent to Pacific Journal of Mathematics, 103 Highland Boulevard, Berkeley, California, 94708.

PUBLISHED BY PACIFIC JOURNAL OF MATHEMATICS, A NON-PROFIT CORPORATION

Printed at Kokusai Bunken Insatsusha (International Academic Printing Co., Ltd.), 270, 3-chome Totsuka-cho, Shinjuku-ku, Tokyo 160, Japan

* C. R. DePrima California Institute of Technology, Pasadena, CA 91109, will replace J. Dugundji until August 1974. 


\section{Pacific Journal of Mathematics}

Vol. 50, No. $2 \quad$ October, 1974

Mustafa Agah Akcoglu, John Philip Huneke and Hermann Rost, A counter example to the Blum Hanson theorem in general spaces .............

Huzihiro Araki, Some properties of modular conjugation operator of von

Neumann algebras and a non-commutative Radon-Nikodym theorem

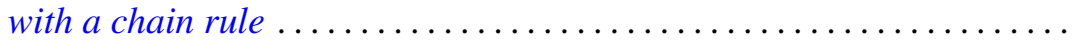

E. F. Beckenbach, Fook H. Eng and Richard Edward Tafel, Global properties of rational and logarithmico-rational minimal surfaces .....

David W. Boyd, A new class of infinite sphere packings ............. 383

K. G. Choo, Whitehead Groups of twisted free associative algebras ........

Charles Kam-Tai Chui and Milton N. Parnes, Limit sets of power series

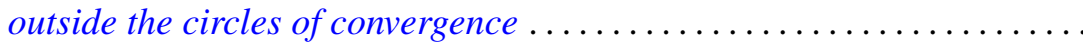

Allan Clark and John Harwood Ewing, The realization of polynomial

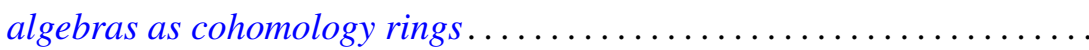

Dennis Garbanati, Classes of circulants over the p-adic and rational

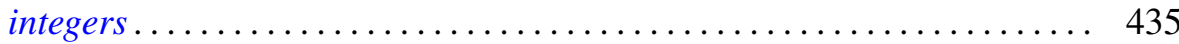

Arjun K. Gupta, On a "square" functional equation ................... 449

David James Hallenbeck and Thomas Harold MacGregor, Subordination and extreme-point theory ............................. 455

Douglas Harris, The local compactness of $v X \ldots \ldots . . . . . . . . . . . .4469$

William Emery Haver, Monotone mappings of a two-disk onto itself which fix the disk's boundary can be canonically approximated by homeomorphisms .................................. 477

Norman Peter Herzberg, On a problem of Hurwitz .................. 485

Chin-Shui Hsu, A class of Abelian groups closed under direct limits and subgroups formation ............................... 495

Bjarni Jónsson and Thomas Paul Whaley, Congruence relations and multiplicity types of algebras.....................

Lowell Duane Loveland, Vertically countable spheres and their wild sets.

Nimrod Megiddo, Kernels of compound games with simple components ....

Russell L. Merris, An identity for matrix functions ........ . .

E. O. Milton, Fourier transforms of odd and even tempered distributions ...

Dix Hayes Pettey, One-one-mappings onto locally connected generalized continua

Mark Bernard Ramras, Orders with finite global dimension

Doron Ravdin, Various types of local homogeneity. .

George Michael Reed, On metrizability of complete Moore spaces ...

Charles Small, Normal bases for quadratic extensions ..

Philip C. Tonne, Polynomials and Hausdorff matrices.... . . 